\title{
ANALISIS KANDUNGAN MERKURI PADA KRIM PEMUTIH ILEGAL DI KECAMATAN PASAR KOTA JAMBI MENGGUNAKAN SPEKTROFOTOMETRI SERAPAN ATOM (SSA)
}

\section{ANALYSIS OF MERCURY CONTENT IN ILLEGAL WHITENING CREAMS IN SUB-DISTRICT JAMBI CITY MARKET BY ATOMIC ABSORPTION SPECTROSCOPY}

\author{
Havizur Rahman ${ }^{1}$, Ilmavia Wilantika ${ }^{1}$, Madyawati Latief ${ }^{2}$ \\ ${ }^{1}$ Pharmacy Study Program, Faculty of Sains dan Teknologi, Jambi University, \\ ${ }^{2}$ Chemistry Study Program, Faculty of Sains dan Teknologi, Jambi University, \\ Jl. Jambi-Muaro Bulian Km 15, Jambi 36122, Indonesia \\ Email: havizurrahman27@unja.ac.id, (Havizur Rahman)
}

\begin{abstract}
ABSTRAK
Merkuri merupakan logam beracun yang dapat menimbulkan efek serius pada kesehatan meskipun pada konsentrasi yang sangat kecil. Dicurigai ada kandungan merkuri pada kosmetik krim pemutih illegal. Tujuan dari penelitian ini adalah untuk menganalisis kandungan dan mengetahui kadar merkuri pada krim pemutih merek $X$. Sampel krim pemutih $\mathrm{X}$ dipilih dengan menggunakan metode purposive sampling. Sebanyak $2 \mathrm{~g}$ sampel dilarutkan dengan cara dekstruksi basah untuk menghilangkan zatzat organik. Identifikasi merkuri menggunakan uji warna dengan reagen $\mathrm{KI}, \mathrm{HCl}$, dan $\mathrm{NaOH}$, sedangkan analisis kuantitatif dilakukan dengan metode Atomic Absorption Spectroscopy (AAS) pada panjang gelombang $253,7 \mathrm{~nm}$. Hasil uji kualitatif menunjukkan bahwa sampel yang direaksikan dengan pereaksi KI menghasilkan endapan merah orange, yang menunjukkan hasil positif adanya merkuri. Namun, dengan pereaksi $\mathrm{NaOH}$ dan $\mathrm{HCl}$ tidak menunjukkan hasil reaksi positif. Semua sampel teridentifikasi kandungan merkuri, dengan kadar masing-masing sampel 0,29;0,289;0,201;0,179;0,265;0,263; 0,$193 ; 0,194 ; 0,328$; dan 0,304 ppm. Krim pemutih ilegal merek X positif mengandung merkuri dengan kadar merkuri rata-rata 0,251 ppm.
\end{abstract}

Kata kunci: ilegal, krim pemutih, merkuri, SSA.

\begin{abstract}
Mercury is a toxic metal causing serious effects on health. It is suspected to be adulterated in the illegal whitening creams. The purpose of this study was to qualitative and quantitatively analyze mercury in brand $X$, an illegal whitening cream. The samples of $X$ whitening cream were selected using purposive sampling method. The samples $(2 \mathrm{~g})$ were dissolved with wet destruction to remove organic substances. The qualitative identification of mercury was performed by the color test using $\mathrm{Kl}, \mathrm{HCl}$, and $\mathrm{NaOH}$ as the reagents, while the quantitative analysis was carried out by the Atomic Absorption Spectroscopy (AAS) method at a wavelength of $253.7 \mathrm{~nm}$. The qualitative analysis
\end{abstract}


resulted that the samples showed a positive result with $\mathrm{KI}$ and producing the orange-red precipitates. However, the samples showed negative results with $\mathrm{NaOH}$ and $\mathrm{HCl}$. All samples contained mercury, with the concentrations of 0.29, 0.289, 0.201, 0.179, 0.265, $0.263,0.193,0.194,0.328$, and $0.304 \mathrm{ppm}$, respectively. Hence, the illegal whitening cream ( $X$ brand) was positively containing mercury with the average mercury level of $0.251 \mathrm{ppm}$.

Key words: AAS, illegal, mercury, whitening cream. 


\section{Pendahuluan}

Kosmetik adalah setiap bahan atau sediaan yang dimaksudkan untuk digunakan pada seluruh bagian luar tubuh manusia (epidermis, rambut, kuku, bibir, dan organ genital bagian luar) atau gigi dan membran mukosa di sekitar mulut terutama untuk membersihkan, mewangikan, mengubah penampilan, dan atau memperbaiki bau badan, dan melindungi atau memelihara tubuh pada kondisi baik (Widana, 2014). Salah satu bentuk sediaan kosmetik yang banyak digunakan adalah krim pemutih.

Krim pemutih merupakan campuran bahan kimia dan atau bahan lainnya dengan khasiat bisa memutihkan kulit atau memucatkan noda hitam pada kulit. Krim pemutih sangat bermanfaat bagi wajah yang memiliki berbagai masalah, karena mampu mengembalikan kecerahan kulit dan mengurangi warna hitam pada wajah (Parengkuan et al., 2013). Berbagai macam produk pemutih wajah dijual di pasaran. Ada yang terdaftar di Badan Pengawasan Obat dan Makanan (BPOM), namun ada juga krim pemutih yang tidak teregistrasi/tidak memiliki izin edar.

Krim pemutih yang tidak teregistrasi tersebut perlu diteliti kandungannya, karena selain tidak teregistrasi oleh BPOM, krim tersebut juga dijual bebas di pasaran dan memiliki harga yang relatif murah, mudah didapat, serta dapat memutihkan wajah dalam waktu yang singkat. Selain itu krim tersebut tidak mencantumkan kandungan kimia yang digunakan, penandaan, peringatan efek samping yang akan terjadi, dan tanggal kadaluarsa (Azhara, 2011). Meskipun demikian kaum wanita tetap tertarik menggunakan krim tersebut tanpa mempertimbangkan efek samping dan bahaya yang ditimbulkan.

Merkuri merupakan bahan yang sering digunakan dalam kosmetik. Merkuri yang biasa digunakan adalah merkuri anorganik, yaitu ammoniated mercury. Ammoniated mercury 1-10\% digunakan sebagai bahan pemutih kulit dalam sediaan krim karena berpotensi sebagai bahan pemucat warna kulit. Krim yang mengandung merkuri, awalnya terasa manjur dan membuat kulit tampak putih dan sehat, tetapi lama-kelamaan, kulit dapat menghitam dan bisa menyebabkan jerawat parah (Rohaya et al., 2017).

Paparan merkuri jangka pendek, dalam dosis tinggi bisa menyebabkan 
muntah-muntah, diare dan kerusakan paru-paru, serta merupakan zat karsinogenik (BPOM, 2007). Pemakaian merkuri dalam jangka waktu yang lama dapat mengakibatkan kanker kulit, kanker payudara, kanker leher rahim, kanker paru-paru, dan jenis kanker lainnya (Christiani, 2009). Karena toksisitasnya terhadap organ-organ ginjal, saraf, dan otak sangat kuat maka pemakaiannya dilarang dalam sediaan kosmetik (BPOM, 2014).

Berbagai teknik digunakan untuk menganalisis merkuri yakni secara kualitatif dengan reaksi warna dan secara kuantitatif untuk menentukan kadar merkuri yang terdapat dalam krim tersebut dengan menggunakan alat salah satunya Spektrofotometer Serapan Atom/SSA (Atomic Absorption Spectrophotometer/AAS), dengan pertimbangan bahwa alat ini merupakan alat yang dapat mengukur kadar logam merkuri dalam jumlah yang kecil, spesifik, dengan hasil yang akurat.

Penelitian in bertujuan untuk mengetahui kadar logam merkuri $(\mathrm{Hg})$ pada krim pemutih yang tidak teregistrasi oleh BPOM yang beredar di Kecamatan Pasar Kota Jambi menggunakan SSA.

\section{Metode Penelitian}

Alat dan Bahan

Bahan-bahan yang digunakan adalah asam nitrat $\left(\mathrm{HNO}_{3}\right) 65 \%$ (Merck), akuades $\left(\mathrm{H}_{2} \mathrm{O}\right)$ (Brataco), akuabides (Brataco), kalium iodida (KI) 0,5 N (Merck), merkuri II klorida (Merck), asam peroksida $30 \%\left(\mathrm{H}_{2} \mathrm{O}_{2}\right)$ (Merck), $\mathrm{NaOH}$ (Merck), $\mathrm{HCl}$ 37\% (Merck), dan 10 sampel krim pemutih wajah merek X. Alat-alat yang digunakan SSA (ASC 7000), timbangan digital (AE Adam PW 254), hot plate (Bibby), lemari asam, labu ukur (Pyrex), pipet mikro, rak tabung reaksi, tabung reaksi, batang pengaduk, gelas beker (Iwaki), corong, gelas ukur, Erlenmeyer (Pyrex), pipet tetes, kertas saring Whatman No. 42.

Jalannya Penelitian

Tahapan penelitian yang dilaksanakan meliputi: perolehan sampel, pembuatan larutan uji secara digesti basah, pengujian sampel secara kualitatif, pengujian sampel secara kuantitatif terdiri dari (pembuatan larutan induk merkuri, pembuatan kurva kalibrasi, validasi metode, pengujian menggunakan SSA, penentuan kadar logam merkuri, serta analisis data.

1. Perolehan sampel

Sampel penelitian yang digunakan adalah krim pemutih 
merek $\mathrm{X}$ yang tidak teregistrasi oleh BPOM, yang beredar di Kecamatan Pasar Jambi. Sampel diambil dari 5 toko yang berbeda, setiap toko diambil 2 sampel, jadi total sampel yang dianalisis adalah 10 sampel. Teknik pengambilan sampel dilakukan secara nonrandom (purposive sampling) dengan kriteria krim pemutih wajah yang paling banyak diminati, murah dengan kisaran harga (Rp 10.000,00-20.000,00), dan tidak teregistrasi.

2. Preparasi larutan uji secara digesti basah

Sampel masing-masing sebanyak 2 g ditimbang, dimasukkan ke dalam gelas beaker $100 \mathrm{ml}$, dan dicampur dengan $10 \mathrm{ml}$ asam nitrat pekat. Sampel dipanaskan di atas hot plate pada suhu $80{ }^{\circ} \mathrm{C}$ sampai kering, kemudian ditambahkan $2 \mathrm{~mL} \mathrm{H}_{2} \mathrm{O}_{2}$ pekat untuk mengoksidasi sepenuhnya bahan organik residu. Bahan sisa diencerkan dengan air deionisasi sampai volume akhir 100 $\mathrm{mL}$. Larutan kemudian disaring menggunakan kertas saring Whatman (The Perkin-Elmer Corporation, 1996).

3. Uji kualitatif (reaksi warna)

a. Reagen $\mathrm{KI}$
Sejumlah $1 \mathrm{ml}$ larutan uji ditambahkan 1-2 tetes larutan KI $0,5 \mathrm{~N}$, lalu diperhatikan dengan saksama. Hasil menunjukkan positif jika terjadi endapan merah orange (Parengkuan et al., 2013).

b. Reagen $\mathrm{NaOH}$

Larutan sampel diambil sebanyak 1-2 ml, dimasukkan ke dalam tabung reaksi, selanjutnya ditambahkan larutan $\mathrm{NaOH}$ 1-2 tetes. Apabila terbentuk endapan kuning maka sampel mengandung merkuri berupa merkurium (II) oksida (Sari et al., 2017)

c. Reagen $\mathrm{HCl}$

Larutan sampel diambil sebanyak 1-2 $\mathrm{ml}$ ditambahkan 5 tetes larutan $\mathrm{HCl}$, hasil menunjukkan positif $\mathrm{Hg}$ jika terbentuk endapan putih (Sari et al., 2017).

4. Uji kuantitatif

a. Pembuatan larutan induk logam raksa $(\mathrm{Hg}) 1000 \mathrm{mg} / \mathrm{L}$ $\mathrm{HgCl}_{2} \quad 0,1354 \mathrm{~g}$ ditimbang, dilarutkan dalam $75 \mathrm{ml}$ air bebas mineral dan $1 \mathrm{ml} \mathrm{HNO}_{3}$ pekat. Volumenya dicukupkan hingga 100 $\mathrm{ml}$ dengan air bebas mineral $(1 \mathrm{ml}$ $\approx 1 \mathrm{mg} \mathrm{Hg})(\mathrm{SNI}, 2011)$. 
b. Pembuatan kurva kalibrasi

Larutan induk 1000 ppm dipipet

$1 \mathrm{ml}$, dimasukkan ke dalam labu

ukur $100 \mathrm{ml}$. Larutan ini selanjutnya diencerkan dengan air bebas mineral dan $\mathrm{HNO}_{3} 1 \mathrm{ml}$ hingga tanda batas, sehingga didapatkan larutan dengan konsentrasi 10 ppm (10000 ppb). Larutan konsentrasi $10 \mathrm{ppm}$ kemudian dipipet $5 \mathrm{ml}$ dan diencerkan dengan air bebas mineral hingga $100 \mathrm{ml}$ dalam labu ukur, sehingga didapatkan larutan dengan konsentrasi 500 ppb. Larutan tersebut dipipet masingmasing 2,5; 5; 10; 20; dan $25 \mathrm{ml}$, kemudian dimasukkan ke dalam labu ukur $250 \mathrm{ml}$ yang berbeda, ditambahkan air bebas mineral hingga tanda tertera, lalu dikocok sampai homogen, sehingga diperoleh larutan dengan konsentrasi $5 ; 10 ; 20 ; 40$, dan 50 ppb. Larutan baku merkuri tersebut diukur menggunakan SSA pada panjang gelombang 253,7 $\mathrm{nm}$, kemudian serapan yang didapatkan diplotkan ke dalam kurva kalibrasi. c. Uji linieritas

Uji linearitas dilakukan setelah pembuatan kurva kalibrasi standar merkuri, sehingga didapatkan persamaan garis regresi. Pada kurva kalibrasi kemudian dihitung koefisien relasi ( $r$ ) dari analisis regresi linier pada Persamaan 1.

$$
y=a+b x
$$

\section{Keterangan:}

$\mathrm{a}=$ Tetapan regresi atau intersep.

$\mathrm{b}=$ Koefisien regresi (slope).

$y=$ Intensitas terbaca.

$\mathrm{x}=$ Konsentrasi.

d. Penentuan Batas LOD dan LOQ

Penentuan Batas LOD dan LOQ dilakukan setelah pembuatan kurva kalibrasi standar merkuri, sehingga didapatkan persamaan garis regresi. Kemudian dihitung nilai simpangan baku, lalu ditentukan nilai LOD dan LOQ melalui garis regresi linier dari kurva kalibrasi berdasarkan rumus pada Persamaan 2-4.

Simpangan baku (SB):

$$
\mathrm{SB}=\sqrt{\frac{\sum(Y-Y i)^{2}}{n-2}}
$$

Batas Deteksi (LOD):

$\mathrm{LOD}=\frac{3 . S B}{\text { slope }}$ 
Batas Kuantitasi (LOQ):

$$
\mathrm{LOQ}=\frac{10 S B}{\text { slope }}
$$

Keterangan:

$\mathrm{Y}=$ Serapan dari daerah standar merkuri.

$\mathrm{Yi}=$ Serapan yang ditentukan dari

persamaan regresi.

$\mathrm{N}=$ Frekuensi penentuan.

slope $=$ Nilai $b$ dari persamaan $(y=a+$ bx).

e. Pengujian menggunakan SSA

Larutan sampel diukur pada panjang gelombang $253,7 \mathrm{~nm}$ dengan cara akuades yang mengandung $\mathrm{HNO}_{3}$ pekat $1 \mathrm{ml} / \mathrm{L}$ akuades dimasukkan. Blanko dimasukkan ke dalam SSA, kemudian dimasukkan sampel yang sudah didestruksi dan dicatat absorbansinya.

f. Penentuan kadar logam merkuri

Data didapatkan dari kadar logam merkuri $(\mathrm{Hg})$ hasil destruksi basah dengan hubungan antara konsentrasi dengan absorbansi, sehingga nilai yang diperoleh adalah slope dan intersep. Kemudian data dimasukkan ke dalam persamaan $y=a+b x$. Setelah itu dihitung kadar logam merkuri dengan rumus seperti pada Persamaan 5 (BPOM, 2014):

$$
\mathrm{Hg}(\mu \mathrm{g} / \mathrm{g})=\frac{C u}{B 0} \times \frac{1}{1000} \times f \times f p
$$

Keterangan:

$\mathrm{Cu}$ : Kadar merkuri yang diperoleh dari hasil pengukuran dinyatakan dalam ( $\mu \mathrm{g} / \mathrm{L})$.

Bo : Bobot sampel (g).

$\mathrm{F} \quad$ : Volume larutan uji (ml).

$\mathrm{Fp}$ : Faktor pengenceran.

\section{Hasil dan Pembahasan}

Uji Kualitatif Logam Merkuri

Analisis kualitatif bertujuan untuk mengetahui keberadaan suatu unsur atau senyawa kimia, baik organik maupun anorganik, dalam hal ini analisis kualitatif yang dilakukan bertujuan untuk mengetahui keberadaan senyawa merkuri pada krim pemutih merek $\mathrm{X}$. Dalam melakukan uji kualitatif, digunakan pereaksi $\mathrm{KI}, \mathrm{NaOH}$, dan $\mathrm{HCl}$ yang akan memberikan endapan merah $\left(\mathrm{HgI}_{2}\right)$ setelah direaksikan dengan $\mathrm{KI}$ jika sampel mengandung merkuri, endapan kuning setelah direaksikan dengan $\mathrm{NaOH}$, dan membentuk endapan putih jika direaksikan dengan $\mathrm{HCl}$. Data uji kualitatif yang diperoleh dapat dilihat pada Tabel 1. 
Tabel 1. Hasil uji kualitatif sampel

\begin{tabular}{ccccc}
\hline No & Nama Sampel & KI & NaOH & $\mathbf{H C l}$ \\
\hline 1 & 1A & + & - & - \\
2 & $1 \mathrm{~B}$ & + & - & - \\
3 & 2A & + & - & - \\
4 & $2 \mathrm{~B}$ & + & - & - \\
5 & $3 \mathrm{~A}$ & + & - & - \\
6 & $3 \mathrm{~B}$ & + & - & - \\
7 & $4 \mathrm{~A}$ & + & - & - \\
8 & $4 \mathrm{~B}$ & + & - & - \\
9 & $5 \mathrm{~A}$ & + & - & - \\
10 & 5B & + & - & - \\
\hline Keterangan: KI= + merkuri (endapan merah orange), $\mathrm{NaOH}=-$ \\
merkuri (tidak membentuk endapan kuning), HCl= - merkuri \\
(tidak membentuk endapan putih).
\end{tabular}

Dari ketiga pereaksi yang digunakan, sampel hanya membentuk endapan pada pereaksi $\mathrm{KI}$ 0,5 N dan tidak berubah saat direaksikan dengan $\mathrm{NaOH}$ dan $\mathrm{HCl}$. Sampel yang mengandung merkuri jika direaksikan dengan 2 (dua) tetes $\mathrm{KI}$ akan membentuk endapan berwarna merah orange. Hasil tersebut selaras dengan penelitian Parengkuan et al. (2013), yang meneliti sampel krim pemutih di Kota Manado secara kualitatif menggunakan pereaksi $\mathrm{KI} \quad 0,5 \mathrm{~N}$. Logam yang mengandung merkuri akan membentuk endapan merah orange jika direaksikan dengan 12 tetes pereaksi. Sari et al. (2017), juga melaporkan bahwa uji kualitatif pada sampel lotion pemutih menggunakan pereaksi KI 1-2 tetes, endapan merah orange akan terbentuk pada sampel yang mengandung logam merkuri. Hal ini berbeda dengan penelitian Rohaya et al., (2017), yang melaporkan endapan merah orange terbentuk setelah sampel yang mengandung merkuri direaksikan dengan 5 tetes $\mathrm{KI}$.

Pada penelitian tersebut, endapan merah orange menghilang setelah pemberian $\mathrm{KI}$ berlebih, hal tersebut sesuai dengan teori Vogel (1990), yang menyatakan bahwa endapan merah orange akan terbentuk pada sampel yang mengandung logam merkuri saat direaksikan dengan $\mathrm{KI}$, dan endapan tersebut akan menghilang dengan penambahan KI berlebih. Dari kesepuluh sampel yang diteliti, semua membentuk endapan merah orange 
yang menandakan bahwa sampel tersebut positif mengandung merkuri. Reaksi yang terjadi antara merkuri dan KI dapat dilihat pada Persamaan 6.

$$
\mathrm{Hg}^{2+}+2 \mathrm{I}^{-} \rightarrow \mathrm{HgI}_{2}
$$

Merkuri yang terdapat dalam sampel bereaksi dengan KI membentuk $\left(\mathrm{HgI}_{2}\right)$ endapan merah-orange. Jika diberikan KI berlebih maka endapan yang terbentuk akan menghilang karena larutan KI sangat sensitif terhadap ion ammonium (Persamaan 7).

$$
\mathrm{HgI}_{2}+2 \mathrm{I}^{-} \rightarrow\left[\mathrm{HgI}_{4}\right]^{2-}
$$

Uji kualitatif berikutnya yang dilakukan pada penelitian ini menggunakan pereaksi $\mathrm{NaOH}$ dan $\mathrm{HCl}$. Pada pengujian tersebut tidak terbentuk endapan kuning saat direaksikan dengan $\mathrm{NaOH}$ dan tidak terbentuk endapan putih saat direaksikan dengan $\mathrm{HCl}$.

Merkuri yang terdapat dalam sampel akan membentuk $\mathrm{Hg}_{2} \mathrm{O}$ atau endapan kuning jika direaksikan dengan $\mathrm{NaOH}$ dan reaksi yang terjadi antara merkuri dan $\mathrm{NaOH}$ dapat dilihat pada Persamaan 8.

$$
\mathrm{Hg}^{2+}+2 \mathrm{OH}^{-} \rightarrow \mathrm{Hg}_{2} \mathrm{O}+\mathrm{H}_{2} \mathrm{O}
$$

Menurut Vogel (1990), merkuri yang terdapat dalam sampel akan membentuk $\mathrm{Hg}_{2} \mathrm{Cl}_{2}$ atau endapan putih ketika direaksikan dengan $\mathrm{HCl}$. Reaksi yang terjadi dapat dilihat pada Persamaan 9.

$$
2 \mathrm{Hg}^{+}+2 \mathrm{Cl}^{-} \rightarrow \mathrm{Hg}_{2} \mathrm{Cl}_{2}
$$

Berdasarkan hasil penelitian tersebut, tidak terbentuknya endapan saat direaksikan dengan $\mathrm{NaOH}$ dan $\mathrm{HCl}$ mungkin disebabkankan oleh rendahnya kandungan merkuri yang terdapat di dalam sampel krim pemutih atau adanya faktor pengganggu dalam larutan sampel. Faktor pengganggu tersebut berupa adanya pengotor yang terbentuk saat dilakukan pemisahan ion pada proses destruksi basah. Hal tersebut sesuai dengan penelitian Sari et al. (2017), uji kualitatif kandungan merkuri menggunakan tiga pereaksi yang berbeda, yakni KI, $\mathrm{NaOH}$, dan pembentukan amalgam dari ketiga pereaksi yang digunakan, hanya pereaksi KI yang bereaksi membentuk endapan merah pada sampel yang positif mengandung merkuri dan larutan sampel tidak bereaksi pada penggunaan pereaksi $\mathrm{NaOH}$ dan amalgam. 
Vol.16 No. 01 Juli 2019

\section{Uji Kuantitatif Logam Merkuri}

Analisis kuantitatif berkaitan dengan penetapan berapa banyak suatu zat tertentu yang terkandung dalam suatu sampel. Zat yang ditetapkan tersebut dinyatakan sebagai analit. Analisis kuantitatif dapat dilakukan dengan menggunakan SSA untuk mengetahui konsentrasi merkuri dalam sampel (Underwood, 2002). SSA digunakan dengan pertimbangan bahwa alat tersebut dapat mengukur kadar logam dalam jumlah kecil dengan hasil yang akurat (Mardin dan Andi, 2012).

\section{Pembuatan Kurva Kalibrasi}

Teknik yang digunakan dalam analisis ini adalah metode kurva kalibrasi yang dilakukan dengan membuat kurva hubungan antara intensitas dan konsentrasi. Kemudian ditentukan daerah linier untuk memberikan batas pengukuran (Kriswarini et al., 2013). Sebagai parameter adanya hubungan linier digunakan koefisien korelasi ( $r$ ) pada analisis regresi linier $y=a+b x$ dan nilai koefisien korelasi ( $r$ ) harus mendekati 1 (Harmita et al., 2014).

Kurva kalibrasi merkuri pada penelitian ini menggunakan 6 konsentrasi yaitu 0, 5, 10, 20, 40, dan 50 ppb. Kurva tersebut menghasilkan persamaan garis linear yaitu $y=0,02470$ $x+0,0458$ koefisien korelasi $(r)=0,9981$. Kurva kalibrasi merkuri dapat dilihat pada Gambar 1.

Linearitas

Uji linearitas termasuk dalam validasi metode yang digunakan untuk membuktikan bahwa parameter tersebut memenuhi persyaratan untuk digunakan dalam penelitian. Berdasarkan Gambar 1, maka dapat dilihat kelinieran dari kurva standar merkuri dengan melihat nilai koefisien relasi $\left(R^{2}\right)$ yang mendekati satu maka slope positif, yang berarti terdapat hubungan linier antara konsentrasi dengan intensitas. Linearitas dari kurva kalibrasi merkuri adalah 0,998 artinya \pm 99\% perubahan absorbansi dipengaruhi oleh perubahan kosentrasi merkuri, sedangkan $\pm 1 \%$ merupakan faktor lain. Berdasarkan hal tersebut maka dapat diketahui bahwa alat yang digunakan dalam keadaan baik.

\section{Penentuan $L O D$ dan $L O Q$}

Selain linearitas, validasi metode dilakukan dengan menentukan nilai LOD dan LOQ berdasarkan kurva kalibrasi merkuri yang telah diketahui sebelumnya. Berdasarkan kurva kalibrasi, didapatkan LOD (Limit of Detection) atau jumlah terkecil analit dalam sampel (batas deteksi) yang dapat 
terdeteksi dan masih bisa memberi respon signifikan dibandingkan dengan blanko adalah 0,004 ppm dan didapatkan nilai LOQ 0,013 ppm. Nilai LOQ adalah batas kuantitasi terkecil analit dalam sampel yang masih dapat memenuhi kriteria cermat dan seksama. Nilai LOQ yang diperoleh menunjukkan bahwa metode pada penelitian tersebut dapat digunakan untuk menganalisis merkuri dengan konsentrasi di atas 0,013 ppm.

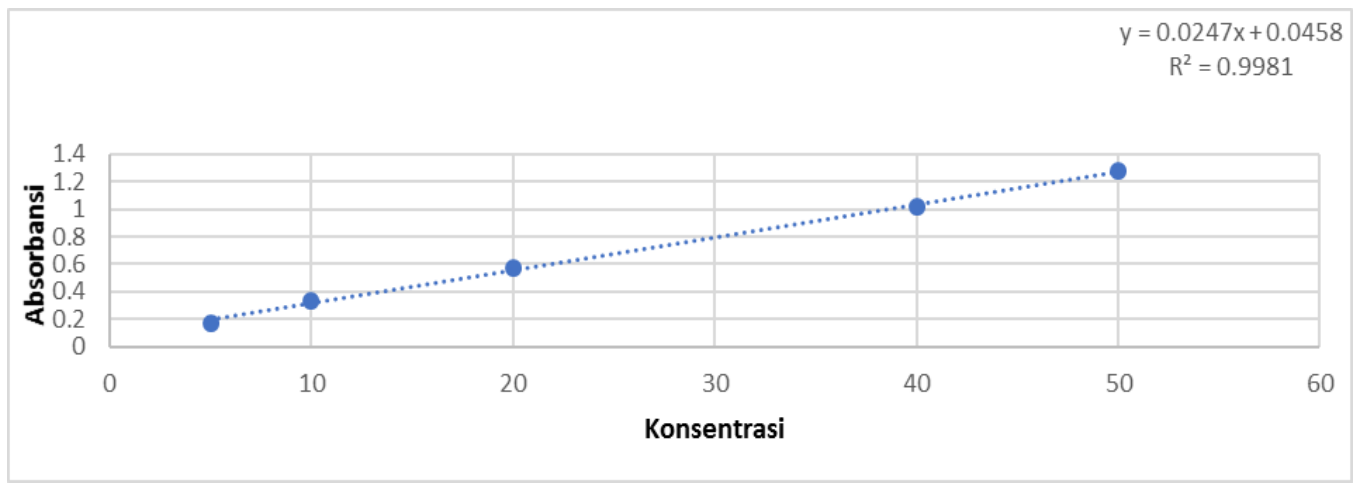

Gambar 1. Kurva kalibrasi merkuri

Berdasarkan uji linearitas, penentuan LOD dan LOQ kurva kalibrasi merkuri tersebut dapat digunakan untuk menentukan kadar merkuri dalam sampel krim pemutih yang dilakukan menggunakan alat SSA dengan panjang gelombang 253,7 $\mathrm{nm}$. Panjang gelombang tersebut dipilih karena memiliki sensitifitas yang paling baik dan tidak berinteraksi dengan logam lainnya yang ada dalam sampel (Robinson, 1996).
Penentuan Kadar Logam Merkuri ( $\mathrm{Hg})$

Pengukuran kadar merkuri pada sampel dimulai dengan pengukuran sampel, larutan baku, dan blanko. Larutan baku yang diuji berfungsi sebagai larutan pembanding merkuri (Hg) yang telah diketahui konsentrasinya, sedangkan blanko berfungsi sebagai larutan pembanding untuk meminimalisir gangguan dalam analisis. Pada penelitian tersebut blanko yang digunakan adalah larutan $\mathrm{HNO}_{3}$ $65 \%$ yang disiapkan berdasarkan metode pada preparasi sampel yang diuji. 
Vol.16 No. 01 Juli 2019

Pengujian sampel dilakukan tiga kali replikasi dengan tujuan untuk menghindari kesalahan preparasi dalam menentukan kadar saat dilakukan analisis.

Logam merkuri $(\mathrm{Hg})$ terdeteksi pada semua sampel yang diteliti. Kadar merkuri tertinggi terdapat pada krim pemutih no 9 sampel 5A yaitu 0,328 ppm. Kadar merkuri terendah terdapat pada krim pemutih No 9 sampel 2B yaitu 0,179 ppm. Dari hasil pengujian didapatkan standar deviasi masingmasing dari 3 kali replikasi adalah 0,000-
0,004 . Nilai standar deviasi menunjukkan sebaran sejumlah nilai data hasil individual dari rata-rata jika prosedur diterapkan secara berulang pada sampel-sampel yang diambil dari campuran yang homogen. Semakin rendah nilai standar deviasi, maka semakin mendekati rata-rata (Harmita, 2004). Dari nilai standar deviasi yang diperoleh menunjukkan bahwa sebaran data mendekati nilai rata-rata. Hasil selengkapnya dapat dilihat pada Tabel 3 dan Gambar 2.

Tabel 3. Kadar merkuri dalam krim pemutih

\begin{tabular}{ccccc}
\hline No & $\begin{array}{c}\text { Nama } \\
\text { Sampel }\end{array}$ & $\begin{array}{c}\text { Rata-rata } \\
\text { Absorbansi } \pm \text { SD }\end{array}$ & $\begin{array}{c}\text { Rata-rata } \\
\text { Konsentrasi (ppb) }\end{array}$ & $\begin{array}{c}\text { Rata-rata } \\
\text { Kadar Hg (ppm) }\end{array}$ \\
\hline 1 & 1A & $0,7875 \pm 0,004$ & 30,028 & 0,299 \\
2 & 1B & $0,7615 \pm 0,004$ & 28,975 & 0,289 \\
3 & 2A & $0,5455 \pm 0,004$ & 20,232 & 0,201 \\
4 & 2B & $0,4913 \pm 0,001$ & 18,036 & 0,179 \\
5 & 3A & $0,7037 \pm 0,000$ & 26,635 & 0,265 \\
6 & 3B & $0,7049 \pm 0,003$ & 26,393 & 0,263 \\
7 & 4A & $0,5240 \pm 0,003$ & 19,363 & 0,193 \\
8 & 4B & $0,5267 \pm 0,002$ & 19,472 & 0,194 \\
9 & 5A & $0,8591 \pm 0,009$ & 32,929 & 0,328 \\
10 & 5B & $0,8001 \pm 0,004$ & 30,539 & 0,304 \\
\hline
\end{tabular}

\footnotetext{
Menurut peraturan kepala Badan Pengawas Obat dan Makanan tahun 2014, merkuri merupakan logam berat yang tidak diperbolehkan terdapat di dalam kosmetika meskipun dalam kadar yang sangat kecil. Hasil penelitian
} kadar merkuri yang terdapat pada krim pemutih tersebut adalah $0,179-0,328$ ppm. Meskipun kadar merkuri tersebut tidak terlalu tinggi, namun penggunaan merkuri dalam kosmetik tetap tidak dibenarkan. Hal tersebut berbeda 
dengan penelitian yang telah dilakukan oleh Rohaya et al. (2017), yang meneliti krim pemutih yang tidak teregistrasi yang beredar di Pasar Inpres Kota Palu dengan kriteria krim yang banyak diminati dan tidak terdaftar. Hasil penelitian tersebut menyatakan bahwa kadar merkuri yang terdapat di dalam krim pemutih adalah 3,52 - 5349,47 ppm. Kadar merkuri yang dilaporkan tersebut cukup tinggi dibandingkan dengan hasil penelitian yang lain. Parengkuan et al. (2013), melaporkan bahwa dari kesepuluh sampel yang diuji terdapat 5 sampel yang tidak teregistrasi dan mengandung kadar merkuri 0,030,06 ppm, kadar merkuri yang terdeteksi tersebut tidak terlalu besar. Penelitian lain pada krim pemutih yang teregistrasi menunjukkan adanya kandungan merkuri seperti pada penelitian yang telah dilakukan oleh Elhag et al. (2015), kadar merkuri pada delapan sampel yang teregistrasi dari delapan sampel yang diteliti hanya terdapat 1 sampel yang tidak tedeteksi merkuri dan lima sampel krim pemutih yang mengandung kadar merkuri cukup tinggi 1,883 -1,1715 ppm. Penelitian pada sampel krim pemutih yang teregistrasi juga dilakukan oleh Erasiska et al., (2015), yang meneliti 6 (enam) sampel krim pemutih wajah, semua sampel terdeteksi merkuri, namun terdapat tiga sampel yang mengandung merkuri melebihi persyaratan yang ditetapkan dengan kadar 1,81-4,18 ppm. Dari beberapa hasil penelitian terdahulu tersebut menunjukkan adanya kandungan merkuri pada sampel teregistrasi dan yang tidak teregistrasi dalam kadar yang rendah sampai kadar yang cukup tinggi.

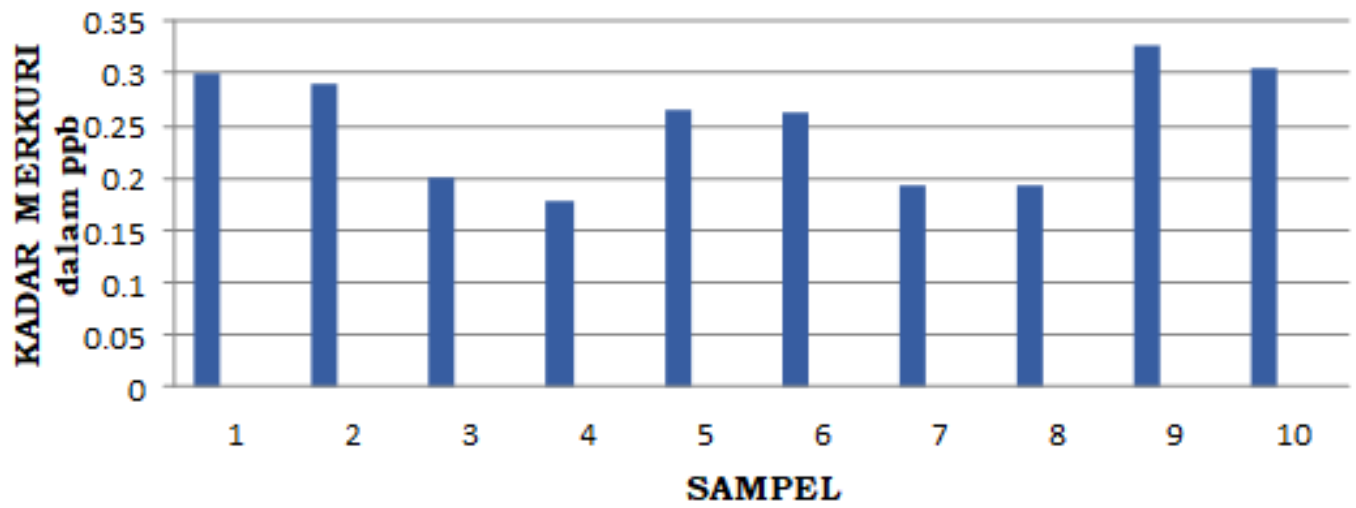

Gambar 2. Grafik kadar merkuri dalam krim pemutih. 
Hasil penelitian yang telah dilakukan menunjukkan bahwa semua sampel krim pemutih merek $X$ positif mengandung merkuri dengan kadar ratarata 0,251 ppm. Penggunakan krim pemutih yang mengandung merkuri harus dihindarkan karena merkuri termasuk logam berat berbahaya, yang dalam konsentrasi kecilpun dapat bersifat racun. Pemakaian merkuri dalam krim pemutih dapat menimbulkan berbagai hal, mulai dari perubahan warna kulit yang pada akhirnya dapat menyebabkan bintik-bintik hitam pada kulit, alergi, iritasi kulit, serta pemakaian dengan dosis tinggi dapat menyebabkan kerusakan permanen otak, ginjal, dan gangguan perkembangan janin, bahkan paparan jangka pendek dalam dosis tinggi juga dapat menyebabkan muntahmuntah, diare, dan kerusakan paru-paru serta merupakan zat karsinogenik (dapat menyebabkan kanker) pada manusia (Parengkuan et al., 2013).

\section{Simpulan}

Sediaan krim pemutih merek $X$ yang tidak teregistrasi oleh BPOM yang beredar di Kecamatan Pasar Kota Jambi positif mengandung merkuri dengan kadar logam merkuri rata-rata 0,251 ppm.

\section{Daftar Pustaka}

Azhara, N.K. 2011. Waspada Bahaya Kosmetik. Yogyakarta: Flashbooks.

BPOM RI. 2007. Kosmetik mengandung bahan berbahaya dan zat warna yang dilarang. Keputusan Kepala Badan Pengawas Obat dan Makanan Republik Indonesia No. HK.00.01.432.6081. Jakarta: BPOM RI.

BPOM RI. 2014. Perubahan Atas Peraturan Kepala Badan Pengawas Obat dan Makanan Nomor Hk.03.1.23.07.11.6662 Tahun 2011 Tentang Persyaratan Cemaran Mikroba dan Logam Berat dalam Kosmetika. Jakarta: BPOM RI.

Christiani. 2009. Analisis kandungan logam merkuri $(\mathrm{Hg})$ dalam krim pemutih yang beredar di Kota Palu Sulawesi Tengah. Palu. 7(4):2313-2317.

Elhag, D.E., Heba, O.O., Ali, A.D. 2015. Investigation of mercury content in cosmetic products by using direct mercury analyzer. American Journal PharmTech Research, 5(5):205-212

Erasiska, E., Bali, S., Hanifah, T.A. 2015. Analisis kandungan logam timbal, kadmium dan merkuri dalam produk krim pemutih wajah. JOM FMIPA, 2(1):123129. 
Harmita. 2014. Petunjuk pelaksanaan validasi metode dan cara perhitungannya. Majalah IImu Kefarmasian, 1(3):117-135.

Kriswarini, R., Anggraini, D., Boybul., Nampira, Y. 2013. Kontrol kurva kalibrasi spektrometer emisi dengan standar aluminium certified reference materials (CRM). Prosiding Seminar Nasional IX SDM Teknologi Nuklir, pp. 300-305, 31 Oktober 2013, Yogyakarta.

Mardin, A.I.K. 2012. Analisis kadar merkuri $(\mathrm{Hg})$ pada sediaan krim pemutih yang beredar di pasaran Nasional. Skripsi. Fakultas IImu Kesehatan, Universitas Islam Negeri Alauddin Makassar.

Parengkuan, K., Fatimawali, Citraningtyas, G. 2013. Analisis kandungan merkuri pada krim pemutih yang beredar di Kota Manado. Pharmacon jurnal ilmiah farmasi, 2(01):62-68.

Robinson. 1996. Atomic Spectroscopy. Edisi 2. New York: Marcel Dekker, Inc.

Rohaya, U., Ibrahim, N., Jamaluddin, J. 2017. Analisis kandungan merkuri $(\mathrm{Hg})$ pada krim pemutih wajah tidak terdaftar yang beredar di Pasar Inpres Kota Palu. Jurnal Farmasi Galenika, 3(1):77-83.
Sari, A.K., Alfiannor, M.M., Noverda, A., Pratiwi, M.E. 2017. Analisis kualitatif merkuri pada lotion pemutih yang dijual di online shop daerah Kota Banjarmasin. Jurnal IImiah Ibnu Sina, 2(1):1319.

SNI. 2011. Cara uji Raksa (Hg) Secara Spektrofotometri Serapan Atom (SSA) - uap dingin atau Mercury Analyzer. SNI 6989.78-2011. Badan Standarisasi Nasional, Jakarta.

The Perkin-Elmer. 1996. Analytical Methods for Atomic Absorption Spectroscopy. United States of America: The Perkin-Elmer Corporation.

Underwood, D. 2002. Analisis Kimia Kuantitatif. Edisi 5. Penerjemah Pudjaatmaka, A.H. Jakarta: Erlangga.

Vogel. 1990. Analisis Anorganik Kualitatif Makro dan Semimikro. Edisi 5. Penerjemah Setiono dan Pudjaatmaka, A.H. Jakarta: PT Kalman Medika Pusaka.

Widana, G.A.B. 2014. Analisis Obat Kosmetik dan Makanan. Yogyakarta: Graha Ilmu. 